\title{
COMMON STRUCTURES OF ASSET-BACKED SECURITIES AND THEIR RISKS
}

\author{
Tarun Sabarwal*
}

\begin{abstract}
In recent years, one area of growing concern in corporate governance is the accounting and transfer of risk using special purpose entities (or trusts). Such entities are used widely in issuing asset-backed securities. This paper provides an overview of the asset-backed securities market, and discusses the common structures used in this market to transform the risks associated with the underlying collateral into risks associated with the issued securities. Understanding these structures is essential to understanding the allocation and transfer of risk among the different parties in an asset-backed transaction - the originator, the special-purpose entity, investors, and related parties such as insurance guarantors. Understanding these structures is also essential in proposing potential solutions to regulatory and accounting concerns about the transfer of risks in asset-backed securities.
\end{abstract}

Keywords: asset-backed securities, structured finance, special purpose entity, seller recourse, corporate governance

${ }^{\star}$ Department of Economics, Campus Box 1208, Wasfington Vniversity in St. Louis, St. Louis MO 63130-4899, sabarwal@wustl.edu

The author is deeply grateful to Bo6 Anderson for his advice and support. He thanks Bill English, Brian Sack, and AlTeplin for helpful comments.

\section{Introduction}

In recent years, one area of growing concern in corporate governance is the accounting and transfer of risk using special purpose entities (or trusts). Techniques using offbalance- sheet financing can be economically valuable, but these techniques can be misused as well, as shown by well-known cases of corporate malfeasance. Special purpose entities are used widely in the growing market for asset-backed securities (ABS), An asset-backed security ${ }^{1}$ is a security that is collateralized, (or backed,) by some financial asset, such as receivables on credit cards, automobile loans, home equity loans, student loans, and so on. In principle, an asset-backed security can be created from almost any stream of receivables. For example, there are securities backed by music royalties, movie revenues, mutual fund fees, and tobacco settlement fees. In practice, for a somewhat active market to exist in securities backed by a particular class of assets, it is important that there be sufficient demand and supply to support ongoing costs of monitoring collateral performance and

\footnotetext{
1 This paper focuses on asset-backed securities other than those included in the mortgage-backed securities (MBS) market, or those included in the commercial mortgage-backed securities (CMBS) market. This definition of the ABS market is consistent with industry practice, and with the somewhat different mechanics and structures of the MBS and CMBS markets.
}

evaluating structural supports, and sufficient standardization of securities to facilitate price transparency and trading liquidity. Examples of assetbacked securities in which there is a market with some regular trade include credit card-backed securities, automobile-backed securities, and home equity-backed securities.

The market for asset-backed securities has grown strongly over time. (At the end of 2004, total amount of ABS outstanding is estimated to be $\$ 1.8$ trillion.) This market has emerged as an attractive alternative source of financing for financial businesses, and can provide attractive alternatives to investors. Using this market, a business can separate the functions of origination and servicing of loans (or, other receivables) from that of funding them, it can increase liquidity of balance sheet assets, it can increase revenues without additional balance sheet financing, and a business with weaker credit quality can access capital market funds usually reserved for businesses with higher credit quality. Moreover, these securities increase investment opportunities for different classes of investors, because receivables from a given pool of collateral can be structured so that securities based on this pool have very different risk and return profiles.

Theoretical considerations for trade-offs in design of different types of securities (for example, corporate debt, equity, and structured non-recourse securities) are explored in Shah and Thakor (1987), Boot and Thakor (1993), Chammanur and John (1996), Glaeser and Kallal (1997), Riddiough (1997), 
Duffie and DeMarzo (1999), Skarabot (2001), and others. These models consider a variety of circumstances, based on asymmetric information, symmetric information, and liquidity costs to highlight factors relevant to issuance and design of different types of securities.

Asset-backed securities can be structured in many different ways, but they havsome common features, as follows. A lender (or originator) pools together and sells loans (or other receivables) to a special-purpose entity (SPE), which in turn issues several securities backed by a beneficial interest in the receivables on these loans. The originator removes these loans off its balance sheet, and can use the proceeds from selling the loans to issue new loans. The originator (who is also the seller) or another servicer services the sold loans for a fee, and proceeds collected on these loans are distributed to the investors and the seller according to the structure of the particular transaction. By varying the distribution of proceeds from the same pool of collateral, assetbacked securities with very different risk and return profiles can be created.

To understand the risks associated with assetbacked securities, it is essential to understand the structure used to transform risk of the underlying collateral into that of the securities. Structures used in the ABS market have evolved to address different market needs, they can be very complex, and they can have markedly different effects on the participants in an asset-backed transaction. These structures are also a subject of policy and regulatory concern about the accounting and transfer of risk from a seller to a special-purpose entity (SPE), and about conflicts between management and control. This paper is organized as follows. The next section provides an overview of the asset-backed securities market. The section after that describes in some detail the main structures used to create asset-backed securities, and risks associated with them. The section after that discusses some recent developments regarding seller recourse and consolidation of SPEs. The last section concludes.

\section{The Market For Asset-Backed Securities}

Among the earliest public issuance of an asset-backed security in the United States is a $\$ 60$ million securitization of automobile loans originated by Marine Midland Bank and securitized in 1985 by the Certificate for Automobile Receivables Trust (CARS, 1985- 1$)^{2}$.The market for asset-backed securities has grown strongly since its inception. A estimated by the Bond Market Association, in the United States, total amount outstanding at the end of 2004 at $\$ 1.8$ trillion. This amount is about 8 percent of total outstanding

\footnotetext{
${ }^{2}$ Hearing before the U.S. House subcommittee on Policy Research and Insurance on "Asset Securitization and Secondary Markets" (July 31, 1991), page 13.
}

bond market debt (\$23.6 trillion), about 33 percent of mortgage-related debt ( $\$ 5.5$ trillion), and about 39 percent of corporate debt ( $\$ 4.7$ trillion) in the United States. In nominal terms, over the last ten years, (1995-2004,) ABS amount outstanding has grown about 19 percent annually, with mortgage-related debt and corporate debt each growing at about 9 percent. Gross public issuance of asset-backed securities remains strong, setting new records in many years. In 2004 , issuance was at an all-time record of about $\$ 0.9$ trillion. ${ }^{3}$

At the end of 2004, the larger sectors of this market are credit card-backed securities (21 percent), home-equity backed securities ${ }^{4}$ (25 percent), automobile-backed securities (13 percent), and collateralized debt obligations (15 percent). Among the other market segments are student loan-backed securities (6 percent), equipment leases ( 4 percent), manufactured housing ( 2 percent), small business loans (such as loans to convenience stores and gas stations), and aircraft leases. There are several reasons for the successful growth of the asset backed securities market. First, this market allows corporations to increase the liquidity of their balance sheet assets ${ }^{5}$ and increase revenues without additional balance sheet financing like equity, bonds, commercial paper, and in the case of depository institutions, consumer deposits ${ }^{6}$.

Once loans are sold to a SPE, the originator removes these loans off its balance sheet, and can use the proceeds to issue new loans. The originator's revenues continue to increase, because it continues to service the sold loans for a fee. Second, this market allows large and small corporations with weak, declining, or no credit ratings to access capital market funds that would otherwise require higher ratings. ${ }^{7}$ Ratings on securities issued in an asset-backed transaction can be higher than those of the corporations originating the underlying collateral, if credit quality of the collateral is better than that of the

\footnotetext{
${ }^{3}$ Source for all data on size of ABS market and size of market components: The Bond Market Association

${ }^{4}$ There is some dissonance regarding classification of home-equity backed securities in the ABS market. These securities are backed by real estate and their asset-backed structures are similar to those used in mortgage-backed securities. In this sense, these securities are closer to mortgage-backed securities. Moreover, the definition of a home-equity loan is not standard in practice; such loans can be second-lien loans, or first-lien sub-prime home loans, or home equity loans (whether prime or not). Following industry practice, this paper includes such securities in ABS.

5 For a theoretical model of the tradeoff between the cost of retaining cash flows on the balance sheet and the liquidity cost (based on asymmetric information) of taking them off the balance sheet, see Duffie and DeMarzo (1999).

${ }^{6}$ Increasing revenues without balance sheet financing reflects favorably on a business, because it can increase earnings per share with the same debt-to-equity ratio.

${ }^{7}$ For example, Moody's downgraded Ford Motor Credit's rating in January 2002, but senior automobilebacked securities issued by Ford Motor Credit in January 2002 and April 2002 continue to be rated Aaa, because of the strength of the underlying collateral, and other credit enhancements.
} 
originating corporations, or if other credit enhancements protect promised cash flows to the same extent as promises of higher credit quality corporations. Finally, to the extent possible, corporations can use this market for accounting arbitrage, and depository institutions can use this market for regulatory capital arbitrage . $^{8}$

\section{Trading Asset-Backed Securities}

In the United States, the process for issuing assetbacked securities in the primary market is similar to that of issuing other securities, such as corporate bonds, and is governed by the Securities Act of 1933, and the Securities Exchange Act of 1934, as amended. Publicly issued asset-backed securities have to satisfy standard SEC registration and disclosure requirements, and have to file periodic financial statements. Credit rating agencies rate these securities, and investment banks underwrite and help place them with investors. The process of trading asset-backed securities in the secondary market is similar to that of trading corporate bonds, and also to some extent, mortgage-backed securities.

Most of the trading is done in over-the-counter markets, with telephone quotes on a security basis. There appear to be no publicly available measures of trading volume, or of number of dealers trading in these securities. Over the last few years, based partly on the successful implementation of electronic systems for trading U.S. Treasury securities, new electronic systems for trading fixed-income securities have been proliferating. A survey by the Bond Market Association shows that at the end of 2004, in the United States and Europe there were 74 electronic trading platforms for trading fixed-income securities and derivatives, with 5 platforms for asset-backed securities in the United States, and 8 in Europe.

However, these electronic trading systems are still evolving, there are no industry-wide standards for them, and it is not evident what percent of fixedincome trading is done using these systems.

Discussions with market participants show that compared to Treasury securities and mortgage-backed securities, many asset-backed securities are not liquid, and their prices are not transparent. This is partly because asset-backed securities are not as standardized as Treasury securities, or even mortgagebacked securities, and investors have to evaluate the different structures, maturity profiles, credit enhancements, and other features of an asset-backed security before trading it. In addition, although there is more standardization within sectors of this market, individual sectors are still small relative to the mortgage-backed securities market, and there are large fixed costs for dealers to develop different

\footnotetext{
${ }^{8}$ See, for example, Thomas (2001), and Stone and Zissu (2000).
}

analytical pricing models, and continually evaluate different types of securities. The most liquid assetbacked securities are those backed by credit cards and automobile loans, the two relatively more established sectors of the ABS market. Within these sectors, securities issued by larger and established issuers (also called "benchmark" or "reference" issuers) are most liquid, and their prices are fairly transparent.

The "price" of an asset-backed security is usually quoted as a spread to a corresponding swap rate. For example, the price of a credit card-backed, AAA-rated security with a two-year maturity by a benchmark issuer might be quoted at 5 basis points (or less) to the two year swap rate (of Treasuries to 1 month LIBOR). Privately available time series of spreads for the highest-rated securities backed by credit cards and automobile loans by benchmark issuers in these sectors show that such securities are priced close to the corresponding swap rate, implying that these securities have little additional risk. Indeed, market participants sometimes view the highest-rated credit card and automobile securities as having default risk close to that of the highest-rated mortgage-backed securities, which are reportedly viewed as a substitute for the default risk-free Treasury securities. The high prices (and correspondingly low spreads) commanded by premier issues of asset-backed securities are reportedly, in part, due to their high and stable credit ratings of such securities.

Asset-backed securities are issued mainly by banks and finance companies (including automobile finance companies, mortgage finance companies, and specialty finance companies), with banks dominating issuance of credit card-backed securities, captive and other automobile financing companies dominating issuance of automobilebacked securities, mortgage finance companies dominating issuance of home equitybacked securities, and specialty finance companies dominating issuance of securities backed by manufactured housing loans, equipment and aircraft leases, and loans to small businesses such as convenience stores and gas stations. Investors in asset-backed securities include a wide range of financial institutions such as banks, insurance companies, finance companies, mutual funds, government-sponsored enterprises, and investment banks.

\section{Structures And Risks}

As asset-backed securities have grown in scope and complexity, concerns about risks associated with them have grown as well. For example, originators are sometimes correctly concerned that their reputation in capital markets will suffer and they might lose an attractive source of funding, if assets securitized by them do not perform as expected, even if the reasons for poor performance are beyond their control. Moreover, credit rating agencies have to understand the increasing complexity of these securities in order 
to correctly classify their credit risks, and investors need sophisticated tools to quantify and price their exposure to these credit risks. Furthermore, regulators and policy makers are concerned that aggressive accounting for asset-backed securities can allow a business to portray itself as less risky than it truly is, it can create conflict between shareholder objectives and managerial incentives, such practices can impair the safety and soundness of depository institutions, and misunderstood risks in this growing market can potentially affect the likelihood of systemic crises in financial markets. To understand the risks associated with an asset-backed security, it is essential to understand its structure. The structure of an assetbacked security determines how cash flows are allocated to different investors, the servicer, and the seller, what protects promised cash flows to investors, and the responsibilities of the seller and servicer of the collateral. There are many structures commonly used in the asset-backed securities market. To address different market needs, the simple structures used in the mortgagebacked securities market in the early 1970s have evolved into considerably complex structures.

Asset-backed structures have the following three general features - pooling and transferring receivables; structuring and issuing securities; servicing, allocating payments, and monitoring.

First, a lender pools together and transfers loans (or, other receivables) to a special-purpose entity (SPE). Standard accounting rules ${ }^{9}$ govern when such a transfer is a sale, a financing, a partial sale, or a part sale and part financing. These distinctions are important, because a transferor can take the transferred assets off its balance sheet in a sale, but it cannot do so in a financing. To the extent that transferors retain servicing rights, or some security interest, or securitize only a fraction of the transferred assets, an asset-backed transaction is closer to a partial sale. In a partial sale, a transferor can take the sold assets off its balance sheet, but continues to account for retained interests on its balance sheet. The transfer of assets to a SPE as a sale should be legally clear enough so that these assets are separate from the transferor even in the event of the transferor's bankruptcy. Such a transfer is sometimes called a bankruptcy-remote transfer, and a SPE is thought of as a bankruptcy-remote entity.

Second, the SPE issues several securities backed by the receivables on these loans. Securities issued by a SPE can be rated differently, depending on the credit risk associated with them. Credit risk in assetbacked structures depends on the performance of the underlying collateral pool of receivables, and on credit enhancements. Important factors affecting

\footnotetext{
9 Financial Accounting Standards Board (FASB) Statement No. 140: "Accounting for Transfers and Servicing of Financial Assets and Extinguishments of Liabilities - a replacement of FASB Statement No. 125," (September 2000).
}

collateral credit quality are a lender's underwriting criteria such as borrower credit score, credit history, loan-to-value ratio, and debt-service coverage ratio, economic variables such as unemployment and bankruptcies, and payment patterns over the age (or, seasoning) of the loans. Credit enhancements affect credit risk by providing more or less protection to promised cash flows for a security. Additional protection can help a security achieve a higher rating, lower protection can help create new securities with differently desired risks, and these differential protections can help place a security on more attractive terms. Common credit enhancements are a senior/subordinated security structure (in such a structure, payments - either interest or principal or both - on a subordinate security are made only after payments on senior securities have been made), a reserve or spread account (in such an account, funds remaining after expenses such as principal and interest payments, charge-offs, and other fees have been paid-off are accumulated, and these can be used when SPE expenses are greater than its income), third party insurance or guarantee of principal and interest payments on the securities, and over-collateralization (usually created by using finance income to pay off principal on some securities before principal on the corresponding share of collateral is collected).

Other credit enhancements include cash funding or a cash collateral account (which usually consists of short-term, highly rated investments purchased either from the seller's own funds, or from funds borrowed from third parties that can be used to make up shortfalls in promised cash flows), a third party letter of credit, a corporate guarantee, a back-up servicer for the loans, discounted receivables for the pool, or other related measures. To achieve a particular rating for a security, asset-backed structures usually must maintain some minimum credit enhancement levels such as a minimum ratio of subordinated principal to either senior principal or total securities principal, minimum spread, minimum insurance by an insurance company that has a particular credit rating, or minimum over-collateralization. Violation of minimum protection levels triggers an "early amortization" event, which starts prepayments on these securities with the available resources of the SPE.

Third, the servicer (usually the same as the seller) collects proceeds on the loans, and these are allocated to the investors, the seller, and the servicer according to the structure of the particular transaction. A servicer can significantly affect cash flows available to an asset-backed transaction, because it controls the collection policy, which influences proceeds collected, charge-offs, and recoveries on the loans. Any income remaining after expenses such as investor and seller payments, charge-offs, and servicing fees are paid off is usually accumulated to some extent in a reserve or spread account, and any further excess is returned to the seller. For public 
securities, periodic reports on the performance of the collateral pool are filed with the Securities and Exchange Commission. Moreover, bond rating agencies publish ratings of asset-backed securities, and update these ratings based on their monitoring of performance of collateral pool, credit enhancements, and probability of default. Asset-backed structures vary significantly in how these general features are implemented. These variations have evolved to address the different cast flow patterns for different collateral types, to address different investor needs, and to reduce the time and expense required for security issuance. For example, master trust structures are particularly suited to handle revolving credit card receivables, issuance and owner trusts provide greater flexibility in creating securities with different maturities and ratings, and issuance trusts considerably reduce the time and expense required to issue a security. Some common structures used in asset-backed transactions are discussed below.

\section{Master Trusts and Issuance Trusts}

A master trust is a special-purpose entity, and assetbacked structures using master trusts are used regularly to issue credit card-backed securities. Structures using master trusts are particularly suited to handle revolving credit card balances, and they can flexibly issue different securities at different times from the same master trust. In a basic master trust structure used to issue credit card-backed securities, an originator of credit card receivables (usually a bank) transfers a pool of such receivables to a master trust, and the master trust can issue different series backed by these receivables. Each series consists of several securities, termed tranches, with possibly different ratings. For each series issued by a master trust, investors have an undivided beneficial interest in the underlying pool of receivables to the extent of the principal amount of the tranches in the series. This amount is termed the invested amount for the series. The sum of invested amounts for each series in the master trust is the total invested amount (or, total investor interest). Pool balance over and above the total invested amount is the seller's interest, in which the seller of the receivables owns an undivided beneficial interest. The originating bank continues to service the credit card accounts. Finance charges collected on a pool of receivables, net of charge-offs, are first pro-rated between the total investor interest and the seller's interest, based on their respective shares in the pool. Master trusts differ in how they allocate the investor share of income to different series. For example, some master trusts allocate income based on the share of outstanding principal for each series, others on the share of expenses due on each series ${ }^{10}$. Master trusts also differ in how they allocate principal payments to different series. For example, master trusts can use principal payments to repay principal on a given series, to purchase additional receivables, to change the payoff schedule of a particular series, or they can accumulate these payments for future purchase of receivables. Within each series, principal and interest allocations for tranches are based on a pre-determined seniority structure. Obligations on senior tranches are fulfilled before those on junior, or subordinated, tranches. Any income remaining after expenses such as investor payments, charge-offs, and servicing fees are paid off is collected in an excess spread account to some prespecified level, and any further excess is returned to the originating bank.

A master trust structure has several idiosyncratic risks, in addition to standard structural risks such as a risk of violation of sale of assets and bankruptcyremoteness, obligor credit risk, and servicing risk. One risk is that timing of cash flows promised to investors might be different from timing of payments on credit card receivables. For example, credit cardbacked securities can have maturities of $2,3,5$, and even 10 years, but credit card receivables usually pay off much more quickly. To address this mismatch, credit card-backed securities usually have a revolving period, an accumulation period, and an amortization period. During the revolving period, principal payments received on credit card balances are used to purchase additional receivables; during the accumulation period, these payments are accumulated in a separate account; and during the amortization period, the accumulated and new payments are passed through to the investors. These periods are based on the historical experience of credit card receivables, and the desired maturity of the securities. Master trusts and credit enhancements have evolved so that principal can be repaid over a pre-determined time period ("controlled" amortization), close to a single date ("soft bullet" amortization), or exactly on a single date ("hard bullet" amortization).

Another risk is that the total investor interest and the seller's interest are limited to receivables generated by credit card accounts, but the seller (or, the originating bank) owns the accounts. This means that the seller controls the terms and conditions on the accounts, whether these accounts are already in the trust, or added over time. To protect investors, credit card-backed securities usually include agreements to the effect that the seller treats accounts in the trust in the same manner as similar accounts in its own portfolio, and account additions should not lower the overall credit quality of the pool. A third risk is that payments on receivables can shrink the pool balance,

\footnotetext{
${ }^{10}$ Different allocation methods have important effects on the credit risk of affected series. For additional details, see Moody's Investor Service (1995)
} 
and under-collateralize total investor interest. To prevent against a sudden decrease in the pool balance, credit card-backed securities usually require a minimum seller's interest. A decrease in seller's interest below the minimum required can cause an early amortization of the securities.

Common credit enhancements in master trust structures include, a senior/subordinated security structure, an excess spread account, a cash collateral account, and a third party letter of credit. Common early amortization triggers are based on minimum subordination ratios, minimum excess spread, minimum yield on the pool receivables, and minimum reserves. One limitation of a senior/subordinate security structure in a master trust is that it requires each issued series to have both senior and subordinate securities, even when investor demand is for only one type of security. In 2000, Citibank introduced a new structure for credit card-backed securities, called an issuance trust, which does not have this limitation. An issuance trust provides several benefits over a master trust; it provides more flexibility in issuing senior/subordinated securities, it potentially increases demand, because pensions funds are eligible to invest in investment-grade securities issued by it, and it significantly reduces the marginal cost of issuing securities. Issuance trusts are now the dominant structure used by major issuers of credit card-backed securities such as Citibank, MBNA, and BankOne. In an issuance trust, the collateral backing the issued securities is not a pool of credit card receivables, but a collateral certificate. This certificate is usually issued by an existing master trust, and it represents a claim on a share of the pool of credit card receivables of that master trust, to the extent of the total invested amount in the issuance trust. An issuance trust issues series like a master trust, and these series are backed by a claim on the collateral certificate. ${ }^{11}$

However, a senior/subordinated structure is not required for each series, only for the collection of all issued series. Credit enhancement levels are set at the trust-level, and not at the series-level. Therefore, when investors demand higher-yielding, lower-rated securities, an issuance trust has the flexibility to issue additional subordinate series, without issuing senior series. Similarly, if trust-level credit enhancement levels are met, an issuance trust can issue senior series without issuing subordinate series.

The master trust issuing the collateral certificate for an issuance trust allocates principal and interest income to the issuance trust by treating the invested amount in the issuance trust as another series. Within

\footnotetext{
${ }^{11}$ Securities issued by an issuance trust can be classified as "notes," because they can be thought of as debt claims on a collateral certificate, and not a direct, undivided beneficial interest in an underlying pool of receivables. Pension funds governed by ERISA can invest in investment-grade notes.
}

the issuance trust, obligations are fulfilled according to the senior/subordinated structure. Risks associated with an issuance trust are broadly similar to those associated with master trusts. In an issuance trust, there can be periods of time when the invested amount in subordinate series is greater than the minimum credit enhancement requirement. Therefore, other things equal, effective credit enhancement for senior securities over the life of an issuance trust can be greater than that in a master trust.

\section{Grantor Trusts, Owner Trusts, and Other Related Trusts}

Grantor trusts and owner trusts are used heavily to issue automobile-backed securities, and REMICs (Real Estate Mortgage Investment Conduits) and residual trusts are the main vehicles used in issuing home equity backed securities, with residual trusts also starting to be used for some automobile-backed securities.

Grantor trusts are similar to the straight passthrough trusts used in the earliest mortgage-backed securities. In a basic grantor trust structure, an originator pools together loans and sells them to a grantor trust, which issues classes of securities backed by these loans. Principal and interest received on the loans, net of expenses such as charge-offs and servicing fees, pass through to the holders of the securities on a pro-rata basis, and there is little flexibility in this allocation. Grantor trusts can issue subordinate classes of securities, but only the interest allocation for the subordinate class can be used to cover credit losses on the senior class. Credit risks in automobile-backed securities issued by grantor trusts are mitigated mainly by a senior/subordinate security structure, and third party insurance provided by one of several monoline insurance companies that specialize in insuring principal and interest payments on bonds. ${ }^{12}$ In an owner trust, there is considerably more flexibility in allocating principal and interest received to different classes of issued securities. For example, both interest and principal due to subordinate securities can be used to pay senior securities. This flexibility allows an owner trust to tailor maturity, risk, and return profiles of issued securities to investor needs. In an owner trust, any income remaining after expenses such as investor payments, charge-offs, and servicing fees are paid off is usually collected in a reserve account up to a pre-specified level, and any further excess is returned to the seller. Credit risks in automobile-backed securities issued by owner trusts are mitigated in part by the same techniques used in grantor trusts, e.g. a senior/subordinate security structure and third party insurance. The flexibility of

\footnotetext{
${ }^{12}$ Examples of such insurance companies are Financial Guaranty Insurance Corporation (FGIC), Mortgage Bond Insurance Associates (MBIA), and Financial Security Assurance (FSA).
} 
an owner trust also allows credit risk to be mitigated by over-collateralization, which is achieved by using excess reserves and excess finance income to prepay some securities before principal on the corresponding share of collateral is collected, thereby leaving more collateral for the remaining classes than the principal due on them. Common early amortization triggers are based on subordination ratios, pool defaults, and reserve funds. A SPE related to an owner trust is a real estate mortgage investment conduit (REMIC), created by the U.S. Tax Reform Act of 1986. A REMIC is like an owner trust in that it can issue several classes of regular securities, but by law it can have only one class of a most subordinate security, called the residual interest. Residual interests have limited liability, and are paid only if income is left after paying all the other classes issued by the conduit. A detailed study of such conduits is beyond the scope of this paper, but these conduits are used extensively to structure mortgage-backed securities, and to issue home equity-backed securities as well.

\section{Seller Recourse and Consolidation Of SPES}

In an asset-backed transaction, sellers sometimes either explicitly or implicitly retain exposure to credit risk associated with the assets sold to a trust. A seller can retain credit risk explicitly by providing a written corporate guarantee to honor the obligations of a trust, or by holding the most subordinated securities, called the residual interest, issued by a trust. In a senior/subordinated security structure, risk is mostly absent in senior securities, more concentrated for subordinated securities, and most concentrated on the most subordinate security (the residual interest), which bears first losses from the collateral pool. Residual interests are almost illiquid, because they have high risk and there is a high degree of uncertainty in evaluating this risk.

A seller can also retain credit risk implicitly by providing resources to a trust when the trust's own resources are insufficient to meet its obligations. For example, in the past, sellers have supported securities issued by credit card master trusts by removing lowerquality accounts from the pool of receivables, by adding higher-quality accounts, by discounting new receivables, and by reducing servicing fees. Sellers have also supported securities issued by automobile trusts by increasing letters of credit and waiving rights to reserve funds. Examples of such support are provided in Moody's Investor Service (1997).

When sellers retain credit risk, investors effectively have some recourse to sellers. Providing recourse is costly for sellers, because they have to bear additional credit risk, but it is also beneficial, because it allows them to develop and maintain a reputation of good credit in capital markets, and provides them attractive access to future financing.
Providing recourse is also costly for creditors of the seller, because their claims on the seller also become riskier, and this can further lead to conflicts between bondholders, shareholders, and management. Explicit recourse obligations are hard to measure, and implicit recourse obligations are hard to even identify. There is no active market in residual interests or interest-only securities, and their valuation methods depend on ad hoc assumptions. In an asset-backed transaction, it can be hard to quantify the share of risk borne by the seller, and that transferred to investors through a SPE. This can result in a potential misclassification on the seller's balance sheet of the true risks associated with the seller's business.

The FASB has proposed interpretations for when a SPE should be consolidated on a seller's (technically, a primary beneficiary's) balance sheet. FASB statement 140 also provides consolidation criteria. These issues are by no means solved yet, and additional amendments to FASB 140 are currently in progress. For example, there is some concern about the inconsistent applications of guidelines to transfers of portions of financial assets, and to accounting for servicing. ${ }^{13}$ When a seller is a depository institution, an increase in its credit risk associated with recourse obligations raises concerns about its safety and soundness. Such concerns have increased with the growth of securitization activities of depository institutions. Indeed, in recent years, regulatory agencies in the United States issued comprehensive rules to define different recourse obligations, set uniform capital charges for them, and remove opportunities for regulatory capital arbitrage. Similar proposals are discussed internationally as well, for example in the Basel discussions on bank capital requirements.

\section{Conclusion}

Against a backdrop of growing concern in corporate governance regarding the accounting and transfer of risk using special purpose entities (or trusts), this paper presents information regarding the use of such entities in the market for asset-backed securities. The market for asset-backed securities has grown strongly since its inception, and it provides an attractive alternative source of funds to financial businesses.

The structures used in asset-backed transactions transform the risk of a pool of collateral into the different risks of securities backed by this pool, these structures have become increasingly sophisticated, and they have evolved with the changing objectives of issuers and investors. Understanding the risks associated with these structures is essential to understanding the risks associated with asset-backed securities, and as the size of the asset-backed

\footnotetext{
${ }^{13}$ See FASB exposure draft dated August 11, 2005.
} 
securities market increases, and the structures associated with these securities become more complex, understanding these risks becomes even more important to originators, issuers, investors, bondholders, shareholders, and regulators in trying to meet their objectives.

\section{References}

1. The Bond Market Association (2004): "eCommerce in the fixed-income markets," the 2004 review of electronic payment systems (December)

2. A.Boot and A. Thakor (1993): "Security Design," Journal of Finance, 48, 1349-1378

3. T. Chemmanur and K. John (1996): "Optimal incorporation, structure of debt contracts, and limited-recourse project financing," Journal of Financial Intermediation, 5, 372-408

4. D. Duffie and P. DeMarzo (1999): "A LiquidityBased Model of Security Design," Econometrica, 67(1), January, 67-99

5. F. Fabozzi (ed.) (2001): The handbook of fixedincome securities, McGraw Hill, New York

6. Financial Accounting Standards Board (2000): "Accounting for Transfers and Servicing of Financial Assets and Extinguishments of Liabilities a replacement of FASB Statement No 125,"StatementNo.140, (September)

7. Financial Accounting Standards Board (2005): "Accounting for Transfers and Servicing of Financial Assets," Exposure Draft, (August)

8. E. Glaeser and H. Kallal (1997): "Thin markets, asymmetric information, and mortgagebacked securities, Journal of Financial Intermediation, 6.
This paper provides an overview of the assetbacked securities market, identifies risks associated with common structures used to issue such securities, and highlights some of the current regulatory and accounting concerns associated with this industry.

9. Moody's Investor Service (1997): "The Costs and Benefits of Supporting "Troubled" Asset-Backed Securities: Has the Balance Shifted?" report, January

10. Moody's Investor Service (1995): “Credit Card Master Trusts: Assessing The Risks of Cash Flow Allocations," report, May

11. T. J. Riddiough (1997): "Optimal design and governance of asset-backed securities," Journal of Financial Intermediation, 6, 121-152

12. S. Shah and A. Thakor (1987): "Optimal capital structure and project financing," Journal of Economic Theory, 42, 209-243

13. J. Skarabot (2001): "Asset Securitization and optimal asset structure of the firm," working paper, University of California at Berkeley

14. C. A. Stone and A. Zissu (2000): "Securitization: the transformation of illiquid financial assets into liquid capital market securities, examples from the European market," Financial Markets, Institutions, and Instruments, 9, August, 133-278

15. H. Thomas (2001): "Effect of asset securitization on seller claimants," Journal of Financial Intermediation, 10(3), July, 306-330

16. U.S. House subcommittee on Policy Research and Insurance on "Asset Securitization and Secondary Markets" (July 31, 1991), hearing. 